\title{
Chlorinated Diphenyl Ethers in Sediments, Biota, and the Water Column from Coastal British Columbia, Canada
}

\author{
SIERRA RAYNE*,1, MICHAEL G. IKONOMOU², and CHRIS GARRETT ${ }^{3}$ \\ ${ }^{1}$ Chemistry, Earth \& Environmental Sciences, The University of British Columbia at Okanagan \\ Kelowna, British Columbia, Canada \\ ${ }^{2}$ Ocean Sciences Division, Institute of Ocean Sciences, Fisheries and Oceans Canada \\ Sidney, British Columbia, Canada \\ ${ }^{3}$ Commercial Chemicals Division, Environment Canada \\ Vancouver, British Columbia, Canada
}

* Corresponding author. Current address: Ecologica Environmental Consulting; E-mail: rayne.sierra@gmail.com; Phone: +1.250.490.9796 


\section{INTRODUCTION}

\section{OVERVIEW à}

- Chlorinatẹç diphenyl ethers (CDPEs) are a halogenated diaryl ether contaminant class.

- 209 different mono- through deca-chlorinated CDPE congeners are possible.

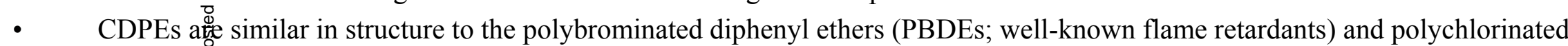
dibenzo[1 1 ; 4 ]dioxins and furans (PCDD/Fs; well-known highly toxic products of combustion and chlorination processes).

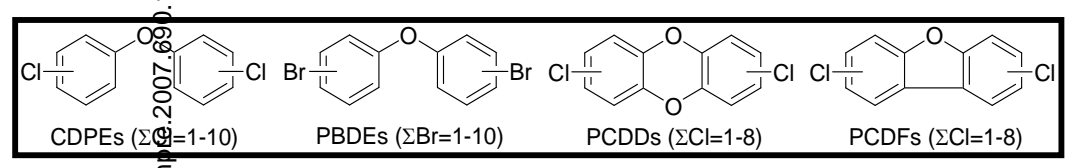

- $\quad$ CDPEs h h.

\section{SOURCES TO ENVIRONMENTAL SYSTEMS}

- Common $\quad$ impurities in technical chlorophenol mixtures (used as wood preservatives) at concentrations up to $100-1000 \mathrm{mg} / \mathrm{L}$.

- Used as $\quad$ Gelectric fluids in capacitors (e.g., Dow Chemical Dielectric Fluid C4) and have historically been used as flame retardants.

- Chlorination of effluents containing suitable precursors is a potential source of CDPEs in environmental systems.

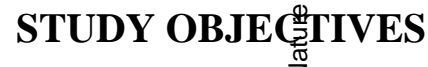

- To better understand the environmental levels and patterns of CDPEs in coastal BC, we analyzed

- $\quad$ archived sediment and biota samples collected between 1988-1996

- from marine regions in the Strait of Georgia near the major urban centers of Vancouver and Victoria, and

- from more remote and pristine marine regions on the North Coast of $\mathrm{BC}$ near the islands of Haida Gwaii and on the western coast of Vancouver Island near the outlet of the Strait of Juan de Fuca.

- $\quad$ and semi-permeable membrane devices (SPMDs) deployed in the Fraser River freshwater system during 1996. 


\section{MATERIALS AND METHODS: \\ SAMPLE COLLECTION AND PROCESSING}

\section{SEDIMENT \$ิAMPLING}

- Sediment grabs collected with modified stainless steel Ponar Grato or stainless steel Smith-MacIntyre grab. Minimum $\stackrel{0}{\circ}$ three grabs were collected at each station.

- Undisturb sample of top $2 \mathrm{~cm}$ of sediment from each grab was cî. 1 lected using a stainless steel spoon after carefully diecanting overlying water.

\section{WATER SAI भiNPLING}

- Semi-pernieable membrane devices (SPMDs; combinatiơn of 3 separate bags measuring $3.2 \mathrm{~cm} \times$ $76.2 \mathrm{~cm}$ ) were placed in the Fraser River between August $6^{\text {th }}$ gand September $30^{\text {th }}$ at $2-3 \mathrm{~cm}$ depth during low tide.

\section{BIOTA SAM M. $\mathbf{T}$ ING}

- $\quad$ Fish were collected using a small otter trawl with a 3.8 $\mathrm{cm}$ mesh net and a $5.8 \mathrm{~m}$ throats towed at 1-1.5 knots.

- Crabs were collected by trawl and crab traps.

- Mussels were collected by hand off rocks, pilings, and docks at low tide.

\section{SAMPLE PROCESSING}

- Details on SPMD construction, deployment locations, and procedures used for extraction and cleanup have been discussed elsewhere (Rayne, S., and Ikonomou, M.G. (2002) Environ. Toxicol. Chem., 21, 2292-2300).

- Dissections were performed on Teflon boards using sterilized stainless steel scalpels, scissors, and forceps.

- Tissues collected for analysis included the following: tail muscle from shrimp and prawns, leg muscle and hepatopancreas from crabs, dorsal muscle (skin removed, liver and gill [without gill arch] from fish), and soft tissue from bivalves.

- Crab hepatopancreas removed shortly after the crab was taken from the water.

- $\quad 30$ to $50 \mathrm{~g}$ aliquots of homogenized tissue were placed in solvent-rinsed and heat treated $125 \mathrm{~mL}$ glass jars.

- Samples were kept frozen at $-20^{\circ} \mathrm{C}$ until analysis. 


\section{MATERIALS AND METHODS: SAMPLE ANALYSES}

\section{PARTICLE SুS SIZE DISTRIBUTIONS}

- Particle size analyses conducted using pipette method and the following classifications:

- silt and clay $(<0.063 \mathrm{~mm}[>230 \mathrm{mesh}])$

- very fine sand (0.063-0.125 mm [230 mesh])

- fine så̀nd (0.125-0.250 mm [120 mesh])

- mediu就 sand (0.250-0.500 mm [60 mesh])

- coarsङ్

- very óarse sand (1.000-2.000 mm [18 mesh])

- $\operatorname{granuFes}(>2.00 \mathrm{~mm}[10 \mathrm{mesh}])$

\section{LIPID CONG}

- Gravimeti̛nicic lipid analyses were performed on extracts using a wet tissue weight.

- Colourimêtetric lipid analyses were performed on a subset of tissue samples. Lipid extract prepared by homogenizing dry tissue sample with $\mathrm{CHCl}_{3}: \mathrm{CH}_{3} \mathrm{OH}(2: 1 \mathrm{v} / \mathrm{v})$, filtering the residue, and diluting the filtrate to a known volume. The lipid concentration was quantified colourimetrically using the sulphophosphovanillin method.

\section{SFR/SVR ANALYSIS}

- Samples were oven dried and then ignited at $550^{\circ} \mathrm{C}$ in a muffle furnace.

- Loss of weight on ignition is sediment volatile residue (SVR); remaining residue is sediment fixed residue (SFR).

CHLORINATED DIPHENYL ETHER (CDPE) ANALYSES

- Samples were first spiked with ${ }^{13} \mathrm{C}$-labeled surrogate standards.

- Sediment samples were solvent extracted on a shaker table.

- Tissue samples were ground with $\mathrm{Na}_{2} \mathrm{SO}_{4}$, eluted through a chromatographic column, and the extract applied to a Biobeads SX-3 column to remove lipids and other large molecular weight components.

- Extracts were cleaned up and fractionated on a Florisil column prior to instrumental analysis by high resolution gas chromatography with high resolution mass spectrometric detection (HRGC-HRMS). 


\section{SAMPLING LOCATIONS}

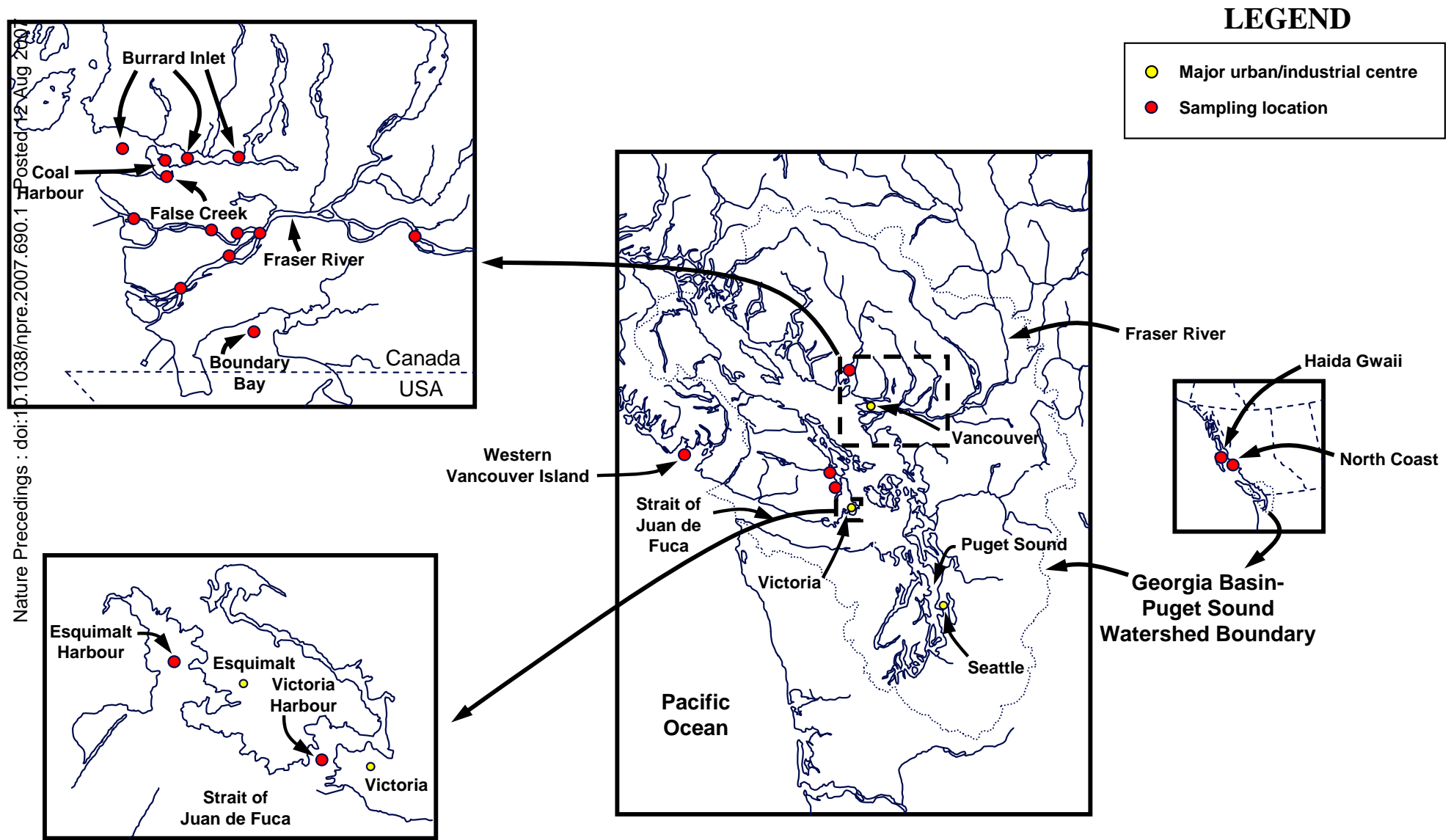




\section{INTER-MATRIX DIFFERENCES AT A SITE: FOOD CHAIN BIOACCUMULATION}

Dungeness Crab Sidestripe Shrimp Sediment

English Sole Sand Sole Dungeness Crab Mussel Sidestripe Shrimp Sediment

English Sole Staghorn Sculpin Dungeness Crab Mussel Humpback Shrimp Pink Shrimp Sediment

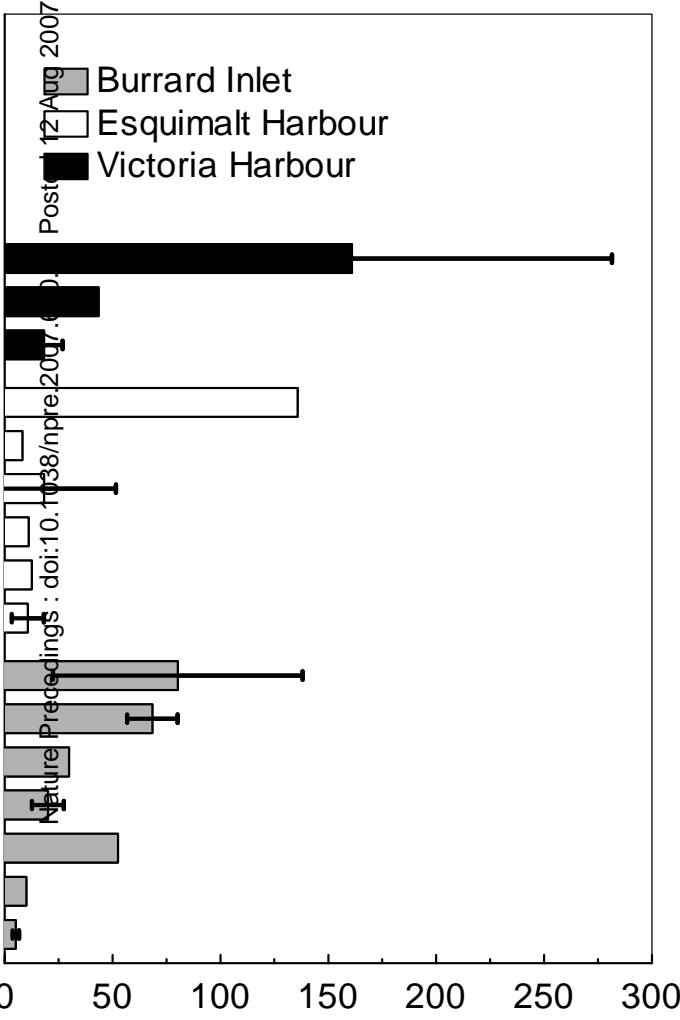

$\Sigma$ CDPE concentration (ng/g lipid wgt or organic C
TRENDS WITHIN MAJOR HARBOURS:

- $\quad$ $\quad$ CDPE increases with higher trophic levels at all sites.

- Pelagic species (sole, sculpin) have higher CDPE burdens than benthic species (crab, shrimp, mussels).

- Lowest concentrations found in sediments.

- Bioaccumulation factors between shrimp/mussels and sediments: 1.0 to10.

- Biomagnification factors betweeen.

- Crab and mussels/shrimp: 0.6 to 3.7

- Sculpin and shrimp: 1.3 to 6.8

- Sole and shrimp: 1.5 to 11

- No significant difference in concentrations between sites within a particular matrix.

\section{SEDIMENT PARTICLE SIZE AND CONTAMINANT LOAD}

- $\quad$ Finer grained sediments in Burrard Inlet accumulate higher mass normalized CDPE concentrations than corresponding coarser sediments from the same locale.

- $\quad$ Typically $>95 \%$ of CDPEs are associated with particulate organic matter (POM; i.e., sediments) vs. dissolved organic matter (DOM).

- $\quad$ Suggests limited potential for mobilization and transport in low DOM systems (e.g., marine environments).

- Supports observations of highly localized sediment contamination near Vancouver and Victoria.

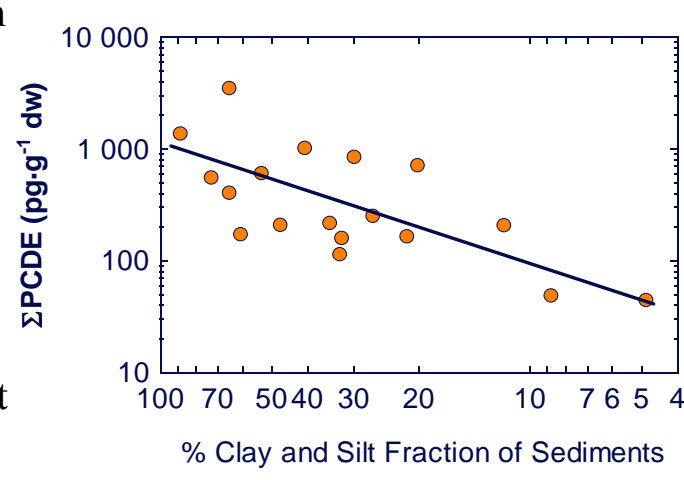




\section{INTRA-MATRIX GEOGRAPHIC VARIATIONS}

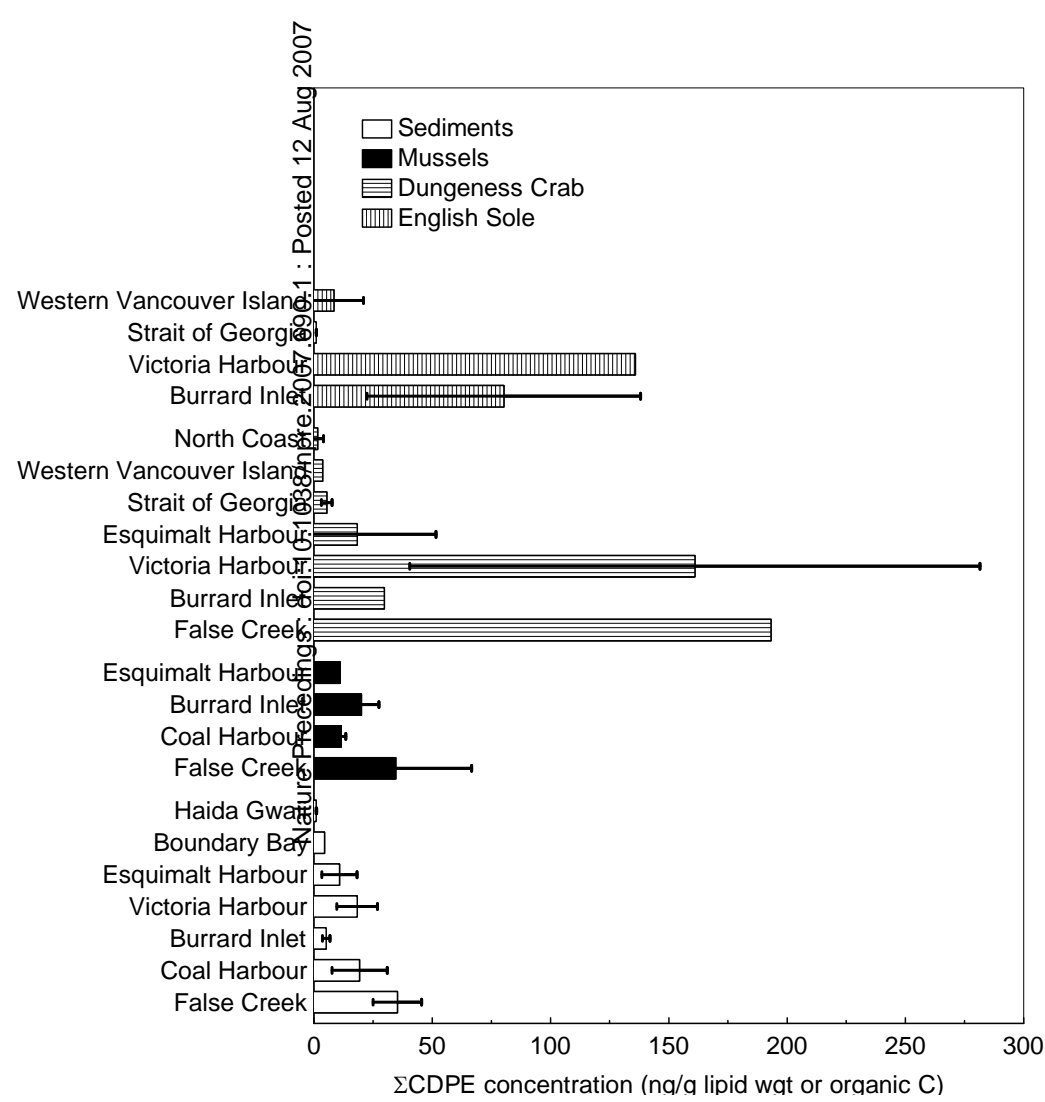

\section{TRENDS:}

- Higher $\Sigma$ CDPE localized in urbanized and industrial regions (Vancouver, Victoria).

- High variation at a site means few significant differences between sites in the major regions.

- Limited CDPE transport away from populated areas.

- Much lower levels even within $50 \mathrm{~km}$ of Vancouver at Boundary Bay and Strait of Georgia sites.

\section{COMPARISON WITH WORLDWIDE DATA:}

- $\quad$ Sediments (ng/g dw):

- Finland: 0.1 to 110

- Baltic Sea: $<0.4$

- Vancouver region: 0.2 to 9.1

- Victoria region: 0.3 to 8.0

- Northern BC: 0.2 to 0.3

- Mussels (ng/g ww):

- Spain: 0.05 to 0.11

- Vancouver region: 0.1 to 1.3

- Esquimalt: 0.5
- $\quad$ Fish (ng/g lw):

- Pike (Finland): $<3$ to 160

- Cod (Norway): 0.4 to 0.5

- Salmon (Finland): 25 to 800

- Trout (Great Lakes): 820

- Sole (Vancouver): 12 to 300

- Sole (Victoria): 140

- Sole (Strait of Georgia): 3 to 21

- Sole (Pacific Ocean): 1 


\section{MATRIX-SPECIFIC CONGENER PROFILES}

\section{CONGENER PATTERNS:}

- Major congerers in all matrices are penta-, hexa-, and hepta-chlorinated

- All mono- through tetra- and octa- through deca-chlorinated congeners below method detecfion limits.

- Cluster analy器s indicates matrix-specific congener profiles, regardless of individual sample levelsaiand geographic locations.

- Both müssels and sediments uncouple into two major sub-groupings, but not based o⿱ levels or location.

- $\quad$ SPMDs enriç্]ed in $\mathrm{C}_{5}$ DPEs $>\mathrm{C}_{6}$ DPEs $>\mathrm{C}_{7}$ DPEs.

- CDE 99.dominates.

- Consiste्gnt with increased mobility of smaller congeners in the water column, and greater uptake rates into SPMD.

- Sediments en⿳亠丷⿵冂丶

- CDEs 182/171/184 dominate.

- Consist㥯t with equilibrium partitioning into sediment organic carbon (i.e., based of $\log \mathrm{K}_{\mathrm{oc}}$ ).

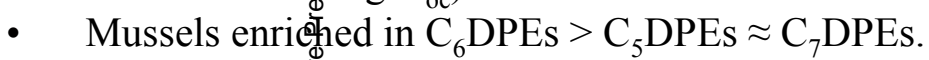

- CDEs 1 1 7/153 dominate.

- Crabs enriched in $\mathrm{C}_{6}$ DPEs $>\mathrm{C}_{5}$ DPEs $>\mathrm{C}_{7}$ DPEs.

- CDEs 147/153 dominate.

- $\quad$ Sole enriched in $\mathrm{C}_{6}$ DPEs $\approx \mathrm{C}_{7}$ DPEs $>\mathrm{C}_{5}$ DPEs.

- CDEs 147/153 and 182/171 dominate.

- Patterns in benthic biota appear to be a 'balance' between higher chlorinated congeners in sediments, and lower chlorinated congeners in water column.

- Pelagic biota reflect preferential biomagnification of hexa- and heptachlorinated homologues.

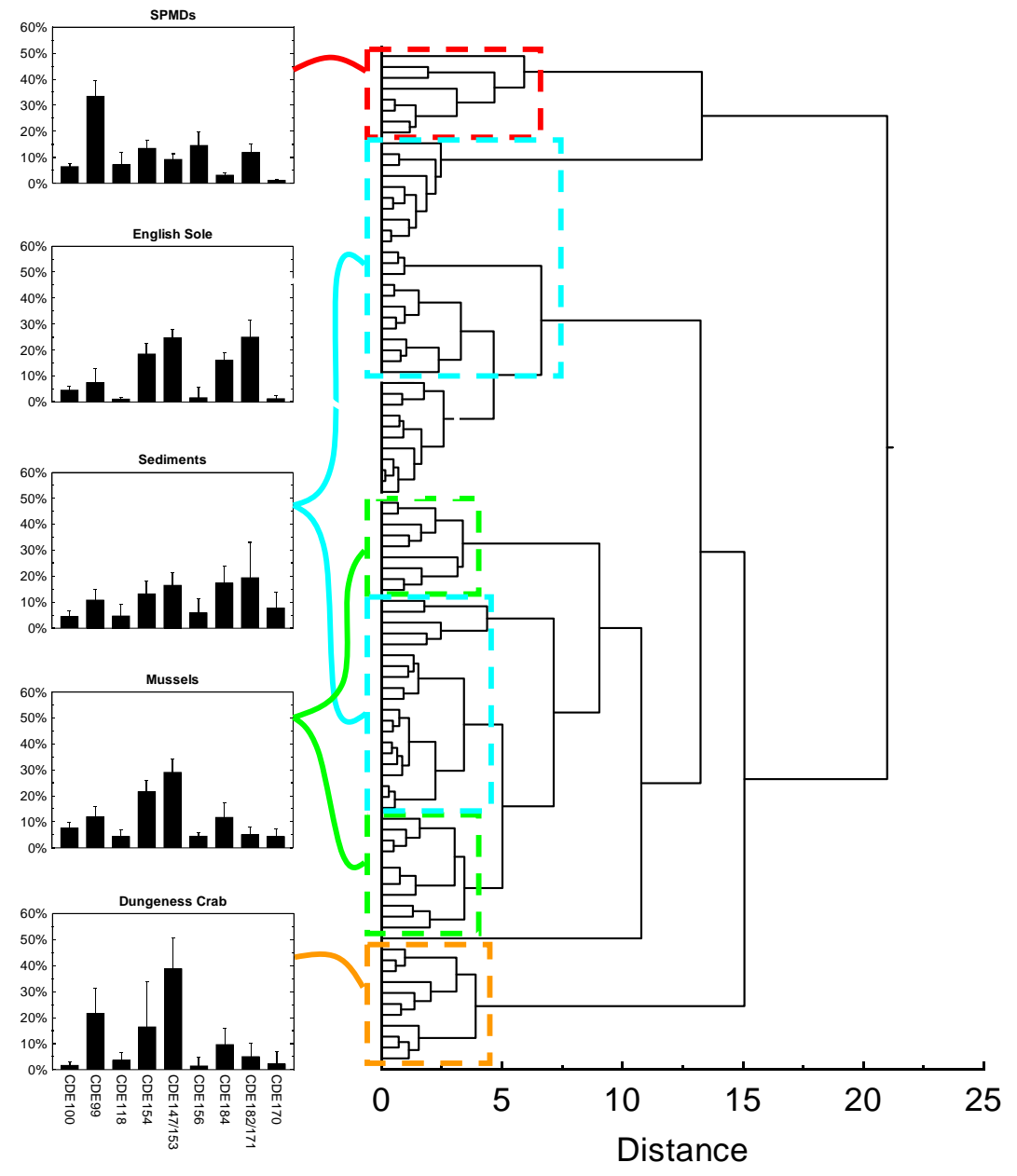




\section{CONCLUSIONS}

- Evidence fos food-chain bioaccumulation/biomagnification at three major harbour sites: pelagic $>$ benthic $>$ sediments.

- Sediments near Vancouver and Victoria much less contaminate with CDPEs than regions in Scandinavia near chlorophen manufacturing sites.

- BC levëls in range of other heavily populated marine areas (8.g., Baltic Sea).

- Mussels neågi major urban BC marine regions have the highest levels reporied worldwide.

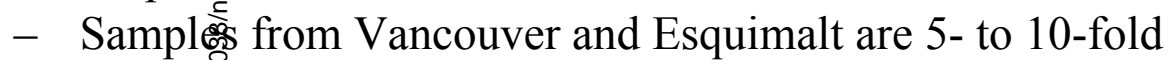
higher than upper range reported in Spain.

- Notable absence of data from other populated areas makes these findings difficult to contextualize.

- Fish knownto be major dietary intake of CDPEs in Spain:

- No conmparable work to date in Canada ...

- Englist Sole in BC marine waters have similar $\Sigma \mathrm{CDPE}$ levels to other areas of N. America and Europe.

- Clear gradient of decreasing concentrations moving from Vancouver/Victoria out into Strait of Georgia and the Pacific Ocean.
- CDPEs appear highly concentrated in sediments and biota near the major urban regions.

- Consistent with physico-chemical properties that favor partitioning into particulate organic carbon on sediments, and lack of mobility in low organic matter marine waters.

- Congener patterns are matrix dependent, and independent of levels or geographic location within a matrix.

- Lower chlorinated congeners dominate in the water column, higher chlorinated in the sediments.

- Biotic patterns in benthic species (mussel/crab) reflect averaging of water and sediment patterns.

- Patterns in pelagic species (sole) show evidence of preferential biomagnification of higher chlorinated congeners.

- Natural Sciences and Engineering Research Council (NSERC)

- Fisheries and Oceans Canada

- Environment Canada

- University of Victoria

- The University of British Columbia at Okanagan 